\title{
11 YEARS OF BIOSTEREOLOGY IN CHINA
}

\author{
HONG SHEN \\ Dept. of Pathology, The First Military Medical University, Guangzhou, 510515, China \\ (Accepted September 12, 2000)
}

\begin{abstract}
Biostereology in China is very active. Here is a brief summary: Organization: The organization of biostereology in China was founded in Nov. 1988. Its name is Chinese Society of Biomedical Stereology (CSBS), and is affiliated to the Chinese Society for Stereology (CSS). The first joint president of CSS/BMC was Prof. Peixuan Tang, the second and now the third, is Prof. Dewen Wang. There are 556 registered members. Academic Congresses: Sessions of the National Biostereological Congress were convened in 1990, 1992, 1996 and 2000. Publications: Four works were written and published in China. One is "Quantitative Histology" (Luji Shi, 1964), another is "Stereological Morphometry For Cell Morphology" (Fusheng Zheng, 1990), the third one is "Practical Biostereological Techniques" (Hong Shen and Yingzhong Shen, 1991) and the fourth one is "Quantitative Cytology and Cytochemistry Techniques" (Genxing Xu, 1994). A Chinese Journal of Stereology and Image Analysis has been published since 1996. Courses: More than ten national training courses on biostereology were held. In some medical universities or colleges, a biostereology course has been set up. Theoretical studies: Some new concepts, parameters and methods for stereology and morphometry were put forward, such as: regular form factor, volume concavity, surface concavity, area concavity, boundary concavity, curve profile area density, positive university for immunohistochemistry stain etc. Application: Stereological methods have been widely applied in biomedical studies. The applied field covered most of the morphological domain of biology. The main applications of biostereology are quantitative pathological diagnosis and prognosis of tumor cells and histostructures. Most studies utilize classical stereological methods. New stereological methods should be popularized and applied in the future. Image Analysis System: Image analysis systems are widely used in biostereological studies. About ten kinds of image analysis systems have been manufactured in China. The most popular is HPIAS, which is made by Huahai Electronic CO.LTD.
\end{abstract}

Keywords: stereology, morphometry, image analysis.

\section{FOUNDATION AND ORGANIZATION}

Biostereology began in China in the 1960's. It is now very active. Chinese Society of Biomedical Stereology (CSBS) was founded in Nov 1988 in Peking. CSBS was associated with the Chinese Society for Stereology (CSS). CSBS is the main part of CSS. The aim of CSBS is to unite all of the scientists and technologists in biomedical stereology, morphometry and image analysis in China, to promote theoretical developments in stereology and to encourage biomedical applications. Fig. 1 shows the society logo of CSBS. Now the registered memberships are 556. The term of the society committee is generally $4-5$ years.

The first round committee was from 1988 to 1994; Prof. Peixuan Tang was elected as president, and Prof. Changqing Ye, Prof. Fusheng Zheng (1928-1989), Prof. Yuanding $\mathrm{Xu}$, Prof. Lian Ding as vice presidents, and Prof. Dewen Wang as the general secretary, and Prof. Xiqing Bai was honorary president.

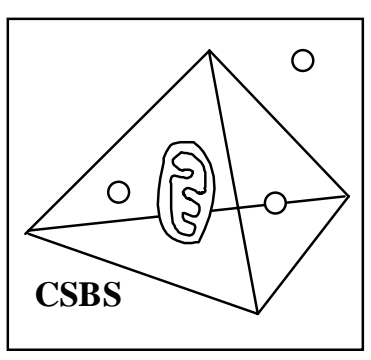

Fig. 1. Logs of CSBS.

The committee consisted of 45 members, 24 were standing committee members. The second session committee run from 1995, and Prof. Dewen Wang was elected as president, and Prof. Lian Ding, Prof. Changen Ben, Prof. Kaicheng Tu, Prof. Yuanding $\mathrm{Xu}$, Prof. Xingzhao $\mathrm{Xu}$, and Prof. Hong Shen as vice presidents, Prof. Kaicheng Tu as the general secretary, Prof. Peixuan Tang is honorary president. The third session committee has run from August 2000, and Prof. Dewen Wang was elected as president again, 
and Prof. Kaicheng Tu, Prof. Hong Shen, Prof. Suojiang Zhang and Prof. Zhengwei Yang as vice presidents, Prof. Zhenshan Cao and Associate Prof. Ruiyun Peng as Joint secretaries. The committee consists of 55 members, 16 are standing committee members.

\section{ACADEMIC CONGRESSES}

Four National Biomedical Stereological Congresses organized under the auspices of CSBS were convened. The First National Biomedical Stereological Congress was convened in June 1990, which was affiliated by the Chinese Society of Pathology (CSP). 102 representatives attended the congress. The second was in November 1991, affiliated by the Chinese Society of Anatomy (CSA) and 132 representatives attended the congress. The third one was in November 1996 with 76 participants. The Fourth National Biomedical Stereological Congress was convened at Dalian City in 16-20 August 2000 and 102 registrants attended. The First Chinese Conference on Computer Image Technique in Pathology was convened in April 1999 was also under the auspices of CSBS. In addition, some local stereological meetings on biostereology were also held. Table 1 shows briefly the information on the convened academic congresses mainly relative to biomedical stereology in China.

Table 1. General Information on Biostereology Congresses in China.

\begin{tabular}{|c|c|c|c|c|c|}
\hline Congress & Time & Place & Organized & $\begin{array}{l}\text { Articles in } \\
\text { biostereology }\end{array}$ & $\begin{array}{l}\text { Registrants in } \\
\text { biostereology }\end{array}$ \\
\hline$\overline{5 C C S I}^{1}$ & 1988.11. & Peking & CSS & $75(69 \%)$ & $110(50 \%)$ \\
\hline NSMMHS $^{2}$ & 1990.6. & Tunxi & CSBS-CSP & $41(76 \%)$ & $44(42 \%)$ \\
\hline CSAMMS $^{3}$ & 1991.11. & Chongqing & CSBS-CSA & $123(100 \%)$ & $133(100)$ \\
\hline $6 \mathrm{CCSI}^{4}$ & 1993.9. & Peking & CSS & $67(80 \%)$ & $72(42 \%)$ \\
\hline $7 \mathrm{CCSI}^{5}$ & 1995.9. & Zhangjiajie & CSS & $47(81 \%)$ & $81(77 \%)$ \\
\hline $3 \mathrm{CCBS}^{6}$ & 1996.11. & Hangzhou & CSBS & $67(100 \%)$ & $53(100 \%)$ \\
\hline $8 \mathrm{CCSI}^{7}$ & 1998.10. & Shenzhen & CSS & $54(77 \%)$ & $38(76 \%)$ \\
\hline $1^{1 C C C I T P}{ }^{8}$ & 1999.4. & Xian & CSBS & $21(68 \%)$ & $21(24 \%)$ \\
\hline $4 \mathrm{CCBS}^{9}$ & 2000.8 . & Dalian & CSBS & $44(36 \%)$ & $66(65 \%)$ \\
\hline
\end{tabular}

5CCSI: The Fifth Chinese Conference on Stereology and Image Analysis

NSMMHS: National Symposium on Morphometry and Molecular Hybridization in Situ

CSAMMS: All China Symposium on Application of Meterology in Morphological Study

6CCSI: The Sixth Chinese Conference on Stereology and Image Analysis

7CCSI: The Seventh Chinese Conference on Stereology and Image Analysis

3CCBS: The Third Chinese Conference on Biomedical Stereology

8CCSI: The Eighth Chinese Conference on Stereology and Image Analysis

1CCCITP: The First Chinese Conference on Computer Image Technique in Pathology

4CCBS: The Fourth Chinese Conference on Biomedical Stereology

\section{PUBLICATIONS}

Four books on biomedical stereology and morphometry were written and published in China. The first one is "Quantitative Histology" which was written by Prof. Luji Shi and published by Science Publishing House of China in 1964. This book marks the beginning of Chinese stereology. The second is "Stereological Morphometry for Cell Morphology", which was written by Prof. Fusheng Zhen (19281989) and published by Joint Publishing House of Beijing Medical University and Peking Union Medical University in 1990. The third one is "Practical Biostereological Technique", written by
Prof. Hong Shen and Yingzhong Shen and published by Publishing House of Zhong Shan University in 1991. The Fourth one is "Technique of Quantitative Cytology and cytochemistry" written by Prof. Genxing $\mathrm{Xu}$ and published by Publishing House of Science and Technology of Ji Ling Province in 1994. Some books contained chapters on biostereology.

A journal of the CSS has been published quarterly under the name Chinese Journal of Stereology and Image Analysis from 1996. It publishes original scientific articles on theoretical and applied research of stereology and image analysis as well as descriptions of new methods, new instruments and 
new techniques. Manuscripts can be submitted in Chinese or English. Editor-in-Chief for the first issue was Prof. Yi Zhang of Beijing Medical University and Zhu Shijun of General Hospital of P.L.A., and the second, current editor is Prof. Guoquan Liu of University of Science and Technology Beijing. About $78 \%$ of the published articles are biomedical. Before 1996, the published articles on biomedical stereology were distributed in a lot of biomorphological linked Journals, such as "Chinese Journal of Physical", "Chinese Journal of Medical Physics", "Chinese Journal of Pathology", "Chinese Journal of Anatomy", "Journal of Biomedical Engineering", "Journal of Mathematical Medicine", "Acta Biophysica Sinica", "Acta Anatomy Sinica", etc. Some articles on stereology are still published in these journals.

\section{COURSES/WORKSHOPS}

To promote the application of stereological techniques in the biomedical domain, a lot of national and local training courses on biostereology have been held since 1985. The total number of national biostereology courses is more than ten. Members of the Organizing Committee were Prof. Changqing Ye, Prof. Kaicheng Tu, Prof. Zhenshen Zhang, Prof. Dewen Wang, Prof. Zhengwei Yang, Prof. Yingzhong Shen, Prof. Guizhen Zhang, Dr. Hongcai Miao, Prof. Brian Weatherhead (Hong Kong) and Prof. Hong Shen. In some medical universities or colleges, such as the First Military Medical University, biostereology has been set up as a course for postgraduate students. Prof. HJG Gundersen from Denmark (1991; 1992; 1994), Prof. NG Wreford from Australia (1991; 1998), Prof. LM Cruz Orive from Switzerland (1992), Prof. TM Mayhew from United Kingdom (1992), Prof. KC Moore, (1995, 2000), Prof. JM Basgen (1995; 2000), Prof. JC Kinnamon (1995) and Prof. B. Knosp (2000) from U.S.A., and Prof. T. Takahashi from Japan (1997) have given Chinese students and scholars one or more lectures/ workshops/courses on stereology, morphometry, or three-dimensional structure reconstruction in China (including Hong Kong). These courses promoted the development of biostereology in China.

\section{THEORETICAL AND METHODOLOGICAL STUDIES}

Some new concepts, parameters and methods for stereology and morphometry have been put forward, such as: volume concavity, surface concavity, area concavity, boundary concavity, curve profile area density, regular form factor (RFF), positive unit for immunohistochemistry stain etc. (Shen, 1997; 1999a; 1999b; 2000).

\section{APPLICATION OF STEREOLOGICAL METHODS}

Stereological methods have been widely applied in biomedical studies in China.

Table 2. Application of stereological methods in different disciplines.

\begin{tabular}{|c|c|c|c|c|c|c|c|c|}
\hline \multirow[t]{2}{*}{ Classification } & \multicolumn{8}{|c|}{ Number of Papers } \\
\hline & Anatomy & $\begin{array}{l}\text { Histology } \\
\text { Embryology }\end{array}$ & $\begin{array}{l}\text { Nontumor } \\
\text { Pathology }\end{array}$ & $\begin{array}{l}\text { Tumor } \\
\text { Pathology }\end{array}$ & Toxicology & Pharmacology & Methodology & Others \\
\hline 5CCSI & 4 & 8 & 19 & 9 & 1 & 7 & 5 & 3 \\
\hline NSMMHS & 1 & 1 & 9 & 13 & 0 & 2 & 2 & 0 \\
\hline CSAMMS & 5 & 24 & 25 & 34 & 4 & 16 & 13 & 2 \\
\hline 6CCSI & 2 & 6 & 10 & 16 & 3 & 8 & 2 & 1 \\
\hline 7CCSI & 0 & 8 & 19 & 3 & 8 & 5 & 4 & 2 \\
\hline 3CCBS & 0 & 8 & 10 & 19 & 8 & 5 & 12 & 6 \\
\hline 8CCSI & 0 & 3 & 15 & 11 & 6 & 2 & 12 & 7 \\
\hline 1CCCITP & 0 & 0 & 2 & 14 & 0 & 0 & 4 & 11 \\
\hline 4CCBS & 0 & 5 & 5 & 9 & 7 & 3 & 5 & 10 \\
\hline Journal* & 2 & 19 & 37 & 37 & 10 & 10 & 25 & 13 \\
\hline Total & 14 & 82 & 151 & 165 & 47 & 58 & 84 & 55 \\
\hline$\%$ & 2.1 & 12.5 & 23.0 & 25.2 & 7.2 & 8.8 & 12.8 & 8.4 \\
\hline
\end{tabular}

*Chinese Journal of Stereology and Image Analysis from 1996 volume 1 (1) to 1999 volume 4 (2) 
Table 3. Application of stereology in different organs and systems.

\begin{tabular}{|c|c|c|c|c|c|c|c|c|c|c|c|c|}
\hline \multirow[t]{2}{*}{ System or Organs } & \multicolumn{12}{|c|}{ Number of Papers } \\
\hline & $\overline{5 C C S I}$ & NSMMHS & CSAMMS & 6CCSI & 7CCSI & 3CCBS & $8 \mathrm{CCSI}$ & 1CCCITP & 4CCBS & Journal* & Total & $\%$ \\
\hline Digestive & 12 & 15 & 23 & 14 & 5 & 16 & 8 & 3 & 4 & 26 & 126 & 21.5 \\
\hline Cardiovascular & 10 & 6 & 14 & 4 & 7 & 2 & 7 & 1 & 1 & 5 & 57 & 9.7 \\
\hline Nervous & 8 & - & 14 & 5 & 4 & 7 & 4 & 0 & 5 & 13 & 60 & 10.2 \\
\hline Blood and Lympha & 2 & - & 16 & 3 & 1 & 3 & 4 & 3 & 5 & 3 & 40 & 6.8 \\
\hline Reproductive & 2 & - & 11 & 5 & 1 & 2 & 5 & 1 & 5 & 13 & 45 & 7.7 \\
\hline Endocrine & 4 & - & 8 & 5 & 3 & 4 & 2 & 0 & 1 & 8 & 35 & 6.0 \\
\hline Respiratory & 5 & 3 & 3 & 3 & 5 & 5 & 2 & 1 & 2 & 7 & 36 & 6.1 \\
\hline Urinary & - & 2 & 4 & 3 & 3 & 5 & 4 & 0 & 1 & 7 & 29 & 4.9 \\
\hline Bone & 2 & - & 3 & 4 & 1 & 1 & 2 & 0 & 1 & 4 & 18 & 3.1 \\
\hline Breast & - & - & 7 & - & 0 & 0 & 1 & 4 & 0 & 9 & 21 & 3.6 \\
\hline Sense & 3 & - & 2 & - & 3 & 2 & 4 & 0 & 1 & 14 & 29 & 4.9 \\
\hline $\begin{array}{l}\text { Limbs and } \\
\text { Skeletal Muscles }\end{array}$ & - & - & 2 & - & 2 & 0 & 2 & 0 & 0 & 3 & 9 & 1.5 \\
\hline Others & 8 & 2 & 16 & 2 & 9 & 12 & 3 & 3 & 6 & 20 & 81 & 13.8 \\
\hline
\end{tabular}

*Chinese Journal of Stereology and Image Analysis from 1996 volume 1 (1) to 1999 volume 4 (2)

The studied fields range from macro to micro, from histology, cytology to ultrastructures, from anatomy, histology and pathology to physiology, pharmacology and toxicology. The main uses of biostereology are quantitative pathological diagnosis and prognosis to tumor cells and histological structures: Table 2 shows the distribution of stereological methods applied in different disciplines based on the count from biostereology relative academic congresses and publications in the Chinese Journal of Stereology and Image Analysis, and table 3 shows the distribution of stereological methods applied in different systems and organs. The results show that stereological methods are chiefly applied to the domain of pathology, especially to tumor pathology and the digestive system. Most studies use classical stereological methods. Prof. Weibel's book Vol. 1 has made a very notable impact on the development of Chinese biostereology (Weibel, 1979). New stereological methods should be further popularized and applied in future.

\section{IMAGE ANALYSIS SYSTEM}

Image analysis systems are widely used in biostereological studies. About ten image analysis systems have been developed in China. The most popular is HPIAS, which is made by Tongji Medical University and Huahai Electronic CO. LTD.

\section{CONCLUSION}

Biostereology in China is very active. CSBS and CSS were founded in 1988. There are 556 registered members. Four sessions of the National Biostereological Congress were convened. Four works were published, and Chinese Journal of Stereology and Image Analysis has been published since 1996. More than ten national training courses on biostereology were held. Some new concepts, parameters and methods for stereology and morphometry, such as: regular form factor, volume concavity, curve profile area density etc., were put forward. Applications covered almost all morphological domains of biology. The main uses are quantitative pathological diagnosis and prognosis of tumor cells and histostructures. Most studies utilize classical stereological methods. About ten kinds of image analysis systems have been manufactured. The most popular is HPIAS.

This review paper was presented at the $\mathrm{X}^{\text {th }}$ International Congress for Stereology, Melbourne, Australia, 1-4 November 1999.

\section{REFERENCES}

Hong Shen (1999a). New concepts and testing methods of concavity for 3D particles. Abstract of Xth International Congress for Stereology. Melbourne, Australia, 1-4 November.

Hong Shen (1999b). Study on the new concept and test methods of curve profile area density in surface area. Abstract of Xth International Congress for Stereology. Melbourne, Australia, 1-4 November.

Hong Shen (2000). A new concept and calculating method for quantitative form description: regular form factor. Analytical and Quantitative Cytology and Histology 22 , in press.

Hong Shen (1997). Study on the testing methods of numerical density in linear structure. Chinese Journal of Stereology and Image Analysis 2(4):193-7.

Weibel ER (1979). Stereological methods. Vol. 1. Practical methods for biological morphometry. London: Academic Press, 1-415. 
Sterio DC (1984). Estimating number, mean sizes and variations in size of particles in 3-D specimens using disectors. J Microsc 134:127-36.
Gundersen HJG (1986). Stereology of arbitrary particles, a review of unbiased number and size and the presentation of some new one, in memory of William R Thompson. J Microsc 143(1):3-45. 
